\title{
PENGEMBANGAN SISTEM INFORMASI SURVEILANS IMUNISASI
}

\author{
Dwi Faqihatus Syarifah Has*)1); Nur Cahyadi MM \\ Prodi Gizi dan Fisioterapi; Sekolah Tinggi Ilmu Kesehatan Delima Persada Gresik \\ Jl Proklamasi No 54 Gresik, Jawa Timur; Indonesia
}

\begin{abstract}
Abstrak
Imunisasi merupakan salah satu upaya promotif dan preventif yang meningkatkan kekebalan seseorang secara aktif terhadap suatu penyakit. Penurunan cakupan kelurahan UCI terjadi di Puskesmas Sukomulyo Kecamatan Manyar Kabupaten Gresik yakni 80\%, penurunan cakupan kelurahan UCI menyebakan meningkatkan jumlah kasus PD3I di wilayah puskesmas Sukomulyo, peningkatan jumlah kasus tersebut sebesar 20\%. Upaya peningkatan kualitas imunisasi dapat memanfaatkan integrasi sistem informasi program imunisasi. Tujuan dari penelitian ini adalah untuk mengembangan model sistem informasi surveilans imunisasi di Puskesmas Sukomulyo Kecamatan Manyar Kabupaten Gresik. Jenis penelitian ini adalah actions research yakni berupa pengembangan system. Langkah dalam penelitian ini : Mendeskripsikan sistem, identifikasi data dan informasi yang dibutuhkan, mengembangkan desain sistem informasi surveilans imunisasi, menyusun aplikasi sistem informasi surveilans imunisasi, dan uji coba serta evaluasi sistem informasi. Berdasarkan hasil penelitian pada analisis masalah sistem menyebutkan bahwa masalah sistem terdapat pada komponen input, proses dan output. Informasi baru yang dibutuhkan adalah pemakaian NIK sebagai kode register, Persentase cakupan imunisasi dasar lengkap, Jumlah balita yang telah diimunisasi/periode, kualitas pemberian vaksin, persentase $\mathrm{UCI} /$ kelurahan, jumlah kasus PD3I/kelurahan, kelurahan dengan kasus PD3I dan wilayah prioritas imunisasi. Berdasarkan hasil uji coba menunjukkan bahwa sistem informasi surveilans imunisasi cukup mudah dan bermanfaat bagi petugas imunisasi di puskesmas Sukomulyo Kecamatan Manyar Kabupaten Gresik.
\end{abstract}

Kata kunci: pengembangan sistem infornasi ; surveilans imunisasi puskesma sukomulyo

\begin{abstract}
[DEVELOPMENT OF IMMUNIZATION SURVEILANS INFORMATION SYSTEM] Immunization is one of the promotive and preventive efforts that actively increase a person's immunity to a disease. The coverage UCI in Sukomulyo Health Center Manyar District Gresik has not been followed by a decrease in cases of PD3I in Sukomulyo District until 20\%. Efforts to improve the quality of immunization can take advantage of the development of technology, one of which is the integration of information systems immunization program. Develop a model system of immunization surveillance information in Sukomulyo Health Center Manyar District Gresik. This study is a type of research actions in the form of system development. The analysis of immunization system problems and mention that there are system problems at the component input, process and output. The new information are: use of NIK as a register code, the number of complete basic immunization coverage, the number of cases PD3I/village, UCI villages, urban villages with cases PD3I, the quality of vaccine administrastion, the priority areas of immunization, and the prevalence of cases PD3I who have not been immunized. The trial results show that immunization surveillance and information systems are quite easy and useful for immunization in Sukomulyo Health Center Manyar District Gresik.
\end{abstract}

Keywords: infornasi system development, surveillance immunization in Sukomulyo Health Center

\section{Pendahuluan}

Imunisasi merupakan salah satu upaya

*) Correspondence author (Dwi Faqihatus Syarifah Has) E-mail: syareefahaz@gmail.com promotif dan preventif yang meningkatkan kekebalan seseorang secara aktif terhadap suatu penyakit. Data mutakhir dari Direktorat Jenderal Pengendalian Penyakit dan Penyehatan 
Lingkungan Departemen Kesehatan Indonesia menunjukan bahwa cakupan imunisasi di Indonesia dari tahun 2010-2014 terus mengalami peningkatan. Indikator keberhasilan imunisasi di Indonesia, salah satunya adalah Universal Child Imunisazion (UCI). Pada tahun 2013, Standart Universal Child Imunisazion (UCI) WHO adalah $90 \%$. Cakupan desa / kelurahan UCI di Indonesia pada tahun 2013 sebesar 100\% dengan kisaran 13,05\% - 100\% (Kemenkes RI, 2015). Penurunan cakupan kelurahan UCI ini juga terjadi di Puskesmas Sukomulyo Kecamatan Manyar Kabupaten Gresik yakni menjadi $80 \%$, penurunan cakupan kelurahan UCI juga menyebakan meningkatkan jumlah kasus PD3I (Penyakit Yang Dapat Dicegah dengan Imunisasi) di wilayah puskesmas Sukomulyo, peningkatan jumlah kasus tersebut sebesar $20 \%$. Kurangnya kesadaran masyarakat terhadap imunisasi dan belum adanya suatu sistem yang terintegrasi menyebakan penurunan cakupan imunisasi dan peningkatan kasus PD3I (Profil Dinas Kesehatan Kab.Gresik, 2015).

Masalah sistem informasi yang terdapat pada program imunisasi adalah : (i) Belum adanya koordinasi data dan informasi antara program imunisasi dengan surveilans PD3I, terkait dengan status imunisasi dan kejadian kasus PD3I. Sehingga perlu adanya suatu sistem informasi yang dapat menghasilkan informasi tentang status imunisasi, kualitas pemberian vaksin, valid dose sebagai upaya deteksi dini kasus PD3I. (ii) Informasi yang dihasilkan dalam sistem informasi imunisasi hanya berupa laporan bulanan, hal ini belum dapat digunakan untuk perencanaan, monitoring dan evaluasi program secara optimal karena informasi laporan hanya pada cakupan imunisasi. Berdasarkan masalah diatas maka perlu adanya pengembangan sistem informasi surveilans imunisasi dan dapat menjadi upaya preventif untuk deteksi dini terhadap kasus PD3I yg meningkat secara signifikans di Puskesmas Sukomulyo Kecamatan Manyar Kabupaten Gresik. Kajian Masalah : Belum adanya koordinasi data dan informasi antara program imunisasi dan surveilans PD3I di dinas kesehatan kota surabaya, sehingga sistem yang dihasilkan belum adekuat untuk menyediakan data yang berkualitas terkait status imunisasi untuk deteksi kasus PD3I. Tujuan penelitian : Mengembangkan model sistem informasi surveilans imunisasi di Puskesmas Sukomulyo Kecamatan Manyar Kab Gresik hingga pada tahap uji coba.
Jenis penelitian ini adalah actions research berupa pengembangan sistem (system development). Penelitian pengembangan sistem dapat dikatakan menyusun sistem baru untuk menggantikan sistem yang lama secara keseluruhan atau memperbaiki sistem yang telah ada (Jogiyanto, 2005 \& Nurul 2016). Lokasi dan waktu Penelitian: di Puskesmas Sukomulyo Kecamatan Manyar Kab Gresik, mulai bulan April hingga Agustus 2018

Unit penelitian dalam penelitian ini adalah kelurahan. Sistem informasi surveilans imunisasi akan melibatkan beberapa unit penelitian yang akan saling berinteraksi. Informan pada penelitian ini adalah: Kepala Puskesmas, Pemegang Program Imunisasi, Bidan Koordinator, IT Puskesmas, Bidan Desa (5 Orang), dan 2 Bidan dari RS Swasta.

Tahapan dalam pengembangan sistem informasi meliputi kegiatan normalisasi data yaitu proses pengelompokan data ke dalam bentu tabel atau relasi atau file untuk menyatakan entitas dan hubungan sehingga terwujud satu bentuk sistem informasi yang mudah dimodifikasi, Pembuatan Entity Relationship Diagram (ERD) yaitu penyajian data dengan menggunakan entity dan relationship, Perancangan output, output merupakan hasil input yang telah diproses oleh bagian pengolah dan merupakan tujuan akhir dari sistem. Langkah selanjutnya yakni melakukan Uji coba dilakukan terhadap semua yang terlibat langsung untuk memastikan seluruh komponen sistem sudah berjalan sesuai yang diinginkan, dengan dua variable, yaitu: Kemudahan penggunaan (ease of use) dan Kemanfaatan (usefulness).

Cara melakukan uji coba dengan melakukan entry data imunisasi yang sudah ada pada program basis data yang baru, oleh petugas yang terlibat langsung dalam pengelolaan data pelaporan imunisasi. Setelah mencoba petugas diminta memberi tanggapan dan saran masukan tentang sistem informasi baru tersebut.

\section{Hasil dan Pembahasan \\ 3.1 Hasil}

Pengembangan model basis data pada sistem informasi surveians imunisasi berperan penting dalam sistem informasi, antara lain sebagai sumber penyedia data untuk memenuhi kebutuhan informasi bagi pengguna atau pengambil keputusan.

Tahapan awal dalam pengembangan sebuah sistem adalah : deskripsi dan analisis masalah pada program imunisasi. Hasil Analisis masalah

\section{Metode}


pada program imunisasi dan surveilans PD3I mendapatkan masalah yang sama yakni pada tabel berikut:

Tabel 1 Hasil analisis masalah imunisasi.

\begin{tabular}{|c|c|c|}
\hline No & Program imunisasi & Surveilans PD3I \\
\hline \multicolumn{3}{|c|}{ Komponen Input } \\
\hline \multirow[t]{8}{*}{1} & Sumber Data : & Sumber Data : \\
\hline & Data imunisasi berasal & Adanya klinik spesialis, \\
\hline & dari puskesmas, BPM, & Rumah sakit, dan BPM \\
\hline & Rumah Sakit, dan & yang tidak melaporkan \\
\hline & Klinik Spesialis, data & jumlah balita yang \\
\hline & jumlah sasaran dari BPS & diimunisasi . Ada \\
\hline & & beberapa yang \\
\hline & & $\begin{array}{l}\text { melaporkan hanya bila } \\
\text { diminta oleh puskesmas. }\end{array}$ \\
\hline \multicolumn{3}{|c|}{ Komponen Proses } \\
\hline 2 & $\begin{array}{l}\text { Kelengkapan Data } \\
\text { masih } 70 \%\end{array}$ & $\begin{array}{l}\text { Kelengkapan Data } \\
\text { masih } 70 \%\end{array}$ \\
\hline 3 & $\begin{array}{l}\text { Ketepatan Data masih } \\
70 \%\end{array}$ & $\begin{array}{l}\text { Ketepatan Data masih } \\
70 \%\end{array}$ \\
\hline 4 & $\begin{array}{l}\text { Penyajian data masih } \\
\text { berupa data rekapan } \\
\text { dari puskesmas }\end{array}$ & $\begin{array}{l}\text { Penyajian data masih } \\
\text { sederhana yakni } \\
\text { rekapan jumlah kasus }\end{array}$ \\
\hline 5 & $\begin{array}{l}\text { Belum adanya integrasi } \\
\text { data imunisasi dengan } \\
\text { kasus PD3I }\end{array}$ & $\begin{array}{l}\text { Belum adanya integrasi } \\
\text { data riwayat imunisasi } \\
\text { pada kasus PD3I }\end{array}$ \\
\hline \multicolumn{3}{|c|}{ Komponen Output } \\
\hline 6 & $\begin{array}{l}\text { Penyajian data dapat } \\
\text { dibuat dalam bentuk } \\
\text { tabel, grafik dan } \\
\text { informasi lain yang } \\
\text { lebih bermanfaat dalam } \\
\text { pengambilan kebijakan }\end{array}$ & $\begin{array}{l}\text { Disajikan hanya dalam } \\
\text { bentuk tabel, grafik dan } \\
\text { maping angka cakupan } \\
\text { imunisasi, belum adanya } \\
\text { suatu aplikasi yang } \\
\text { dapat menghasilkan } \\
\text { informasi yang cepat } \\
\text { terkait dengan } \\
\text { pengambilan kebijakan }\end{array}$ \\
\hline
\end{tabular}

Berdasarkan analisis masalah program surveilans imunisasi pada table 1, maka dapat disimpulkan bahwa perlu adanya penambahan beberapa informasi pada surveilans imunisasi. Penambahan beberapa informasi pada imunisasi adalah pemakaian NIK sebagai kode Register, persentase cakupan imunisasi dasar lengkap, jumlah balita yang telah diimunisasi pada tiap periode, kualitas pemerian vaksin, Persentase UCI kelurahan, Kelurahan dengan kasus PD3I, dan wilayah Prioritas program Imunisasi.

Pengembangan sistem informasi ini merupakan perancangan pengelolaan berbagai data yang disimpan dalam file, sehingga satu dengan yang lainnya dapat dihubungkan membentuk suatu informasi. Pengembangan sistem informasi surveilans imunisasi ini menggunakan tahapan pembuatan diagram konteks, DFD,
Normalisasi data, dan Entity Relationship Diagram (ERD). Berikut ini adalah tahapan dalam pengembangan sistem informasi surveilans imunisasi :

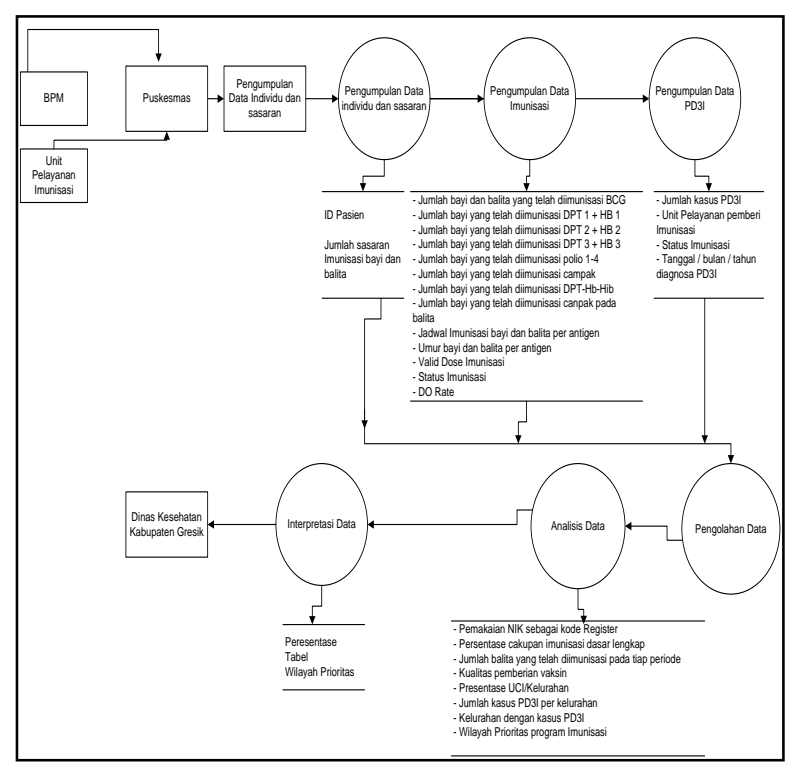

Gambar 1 : Entity Relationship Diagram (ERD)

Dari uraian juga kita dapat membuat DFD level 0 dapat dilihat dalam gambar 2 :

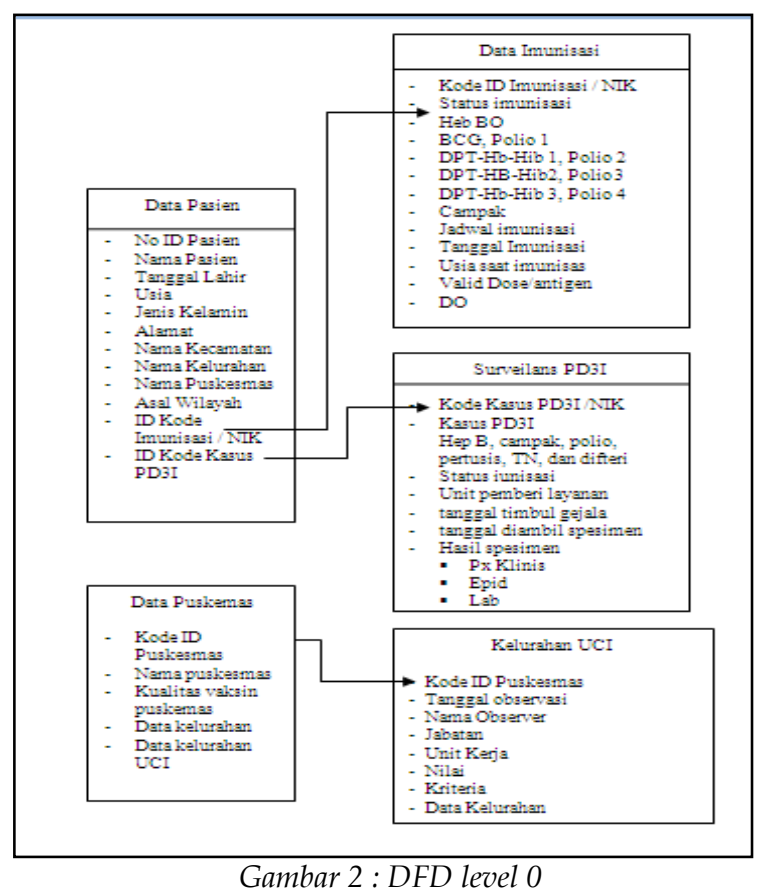

Berikut ini adalah tabel 2 Informasi baru yang dibutuhkan, kebutuhan data dan sumber data : 
Tabel 2 Informasi baru yang dibutuhkan, kebutuhan data dan sumber data :

\begin{tabular}{|c|c|c|c|}
\hline No & $\begin{array}{c}\text { Informasi } \\
\text { baru }\end{array}$ & Kebutuhan data & Sumber data \\
\hline 1 & $\begin{array}{l}\text { Persentase } \\
\text { cakupan } \\
\text { Imunisasi } \\
\text { dasar lengkap }\end{array}$ & $\begin{array}{ll}\text { a. } & \text { Jumlah Bayi } \\
\text { Yang } \\
\text { Diimunisasi } \\
\text { Bcg, Dpt/Hb } \\
\text { Lengkap, Hb } \\
\text { Uninject/0-7 } \\
\text { Hari, Campak } \\
\text { Dan Polio } \\
\text { lengkap } \\
\text { b. Jumlah bayi } \\
\text { sasaran }\end{array}$ & $\begin{array}{ll}\text { a. } & \text { Laporan by } \\
& \text { name by } \\
\text { addres } & \\
\text { dengan } & \text { pemakaian } \\
& \text { NIK } \\
\text { sebagai } & \text { kode } \\
\text { register } \\
\text { pasien dari } \\
\text { puskesmas } \\
\text { b. } \text { Buku } \\
\text { Kohort }\end{array}$ \\
\hline 2 & $\begin{array}{l}\text { Kualitas } \\
\text { pemberian } \\
\text { Vaksin }\end{array}$ & 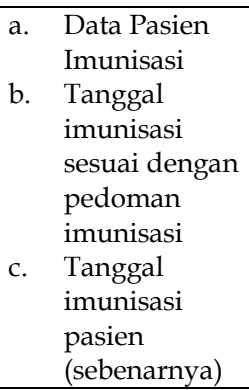 & $\begin{array}{ll}\text { a. } & \text { Buku } \\
& \text { Kohort } \\
& \text { Pasien } \\
\text { b. } & \text { Buku } \\
& \text { Pedoman } \\
& \text { imunisasi } \\
& \text { IDAI }\end{array}$ \\
\hline 3 & $\begin{array}{l}\text { Persentase } \\
\text { UCI } \\
\text { Kelurahan }\end{array}$ & $\begin{array}{l}\text { Cakupan } \\
\text { imunisasi BCG, } \\
\text { DPT/HB 3, Polio } \\
\text { 4, dan campak di } \\
\text { wilayah } \\
\text { kelurahan per } \\
\text { puskesmas }\end{array}$ & $\begin{array}{ll}\text { a. } & \text { Laporan by } \\
& \text { name by } \\
& \text { addres dari } \\
& \text { puskesmas } \\
\text { b. } & \text { Buku } \\
& \text { Kohort }\end{array}$ \\
\hline 4 & $\begin{array}{l}\text { Frekuensi } \\
\text { Kasus PD3I } \\
\text { per kelurahan }\end{array}$ & $\begin{array}{ll}\text { a. Jumlah kasus } \\
\text { PD3I } \\
\text { b. Nama } \\
\text { Kelurahan } \\
\text { c. Nama } \\
\text { Pelayanan } \\
\text { Imunisasi }\end{array}$ & $\begin{array}{ll}\text { a. } & \text { Laporan } \\
& \text { rutin } \\
& \text { surveilans } \\
& \text { PD3I } \\
& \text { puskesmas } \\
& \text { dan RS } \\
\text { b. } & \text { Laporan } \\
& \text { pelacakan } \\
& \text { kasus PD3I } \\
\end{array}$ \\
\hline 5 & $\begin{array}{l}\text { Kelurahan } \\
\text { dengan Kasus } \\
\text { PD3I }\end{array}$ & $\begin{array}{ll}\text { a. Jumlah kasus } \\
\text { PD3I } \\
\text { b. Nama } \\
\text { Kelurahan } \\
\text { c. Nama } \\
\text { Pelayanan } \\
\text { Imunisasi }\end{array}$ & $\begin{array}{ll}\text { a. } & \text { Laporan } \\
& \text { rutin } \\
& \text { surveilans } \\
& \text { PD3I } \\
& \text { puskesmas } \\
& \text { dan RS } \\
\text { b. } & \text { Laporan } \\
& \text { pelacakan } \\
& \text { kasus PD3I }\end{array}$ \\
\hline 6 & $\begin{array}{l}\text { Wilayah } \\
\text { Prioritas } \\
\text { program } \\
\text { imunisasi }\end{array}$ & $\begin{array}{ll}\text { a. } & \text { Nama } \\
& \text { kelurahan } \\
\text { b. } & \text { Cakupan } \\
\text { imunisasi } \\
\text { dasar lengkap } \\
\text { c. DO rate }\end{array}$ & $\begin{array}{l}\text { Rekapan } \\
\text { laporan } \\
\text { imunisasi } \\
\text { puskesmas }\end{array}$ \\
\hline
\end{tabular}

Berdasarkan tabel kebutuhan data diatas, maka didapatkan beberapa input data yang harus disediakan sehingga menghasilkan informasi tersebut.

Hasil pengembangan sistem informasi surveilans imunsisasi pada gambar 3 adalah sebagai berikut :

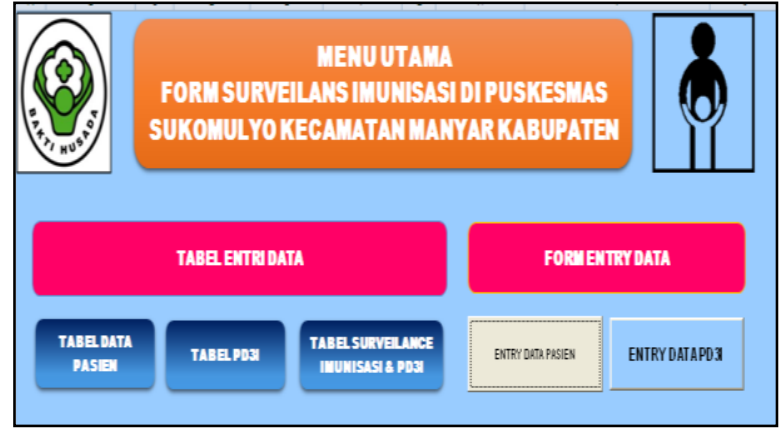

Gambar 3 : Tampilan Menu Utama

Gambar 3 adalah gambar tampilan menu utama sistem informasi surveilans imunisasi di Puskesmas Sukomulyo Kecamatan Manyar Kabupaten Gresik yang telah dikembangkan. Tampilan menu utama terdapat tabel entri data dan form entry data. Pada tabel entry data berisi tabel data pasien, tabel PD3I dan tabel surveilans imunisasi dan PD3I.

Form entry data pasien adalah form yang digunakan untuk mengisikan identitas bayi dan balita yang diimunisasi. Form entry data pasein dan entry data PD3I dikembangkan untuk mengganti laporan by name by adress yang biasa dilaporkan oleh tiap puskemas pada tiap bulannya.

Menu entry data sebagaimana pada gambar 4:

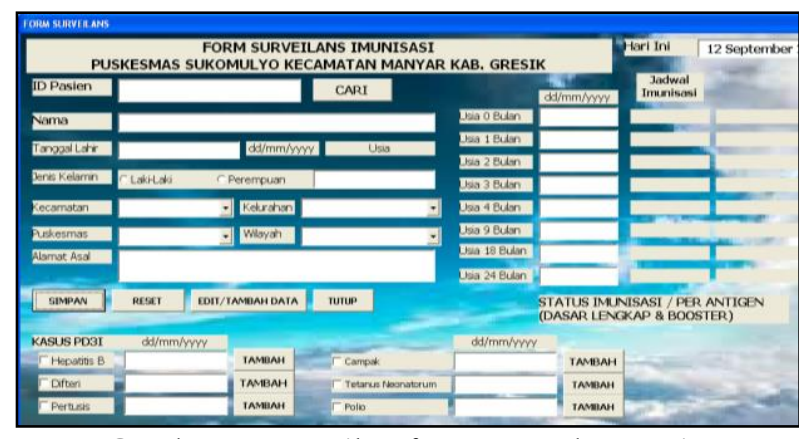

Gambar 4: Tampilan form entry data pasien

Untuk memasukan data imunisasi dan kasus PD3I, pasien harus mempunyai ID yang sama, dalam hal ini ID pasien adalah NIK (Nomor Induk Keluarga) sehingga apabila petugas memasukkan data kasus PD3I maka akan muncul data riwayat status imunisasi pasien. Data yang telah diisikan pada template Microsoft Vicual Basic tersebut maka akan otomatis masuk kedalam masing masing sheet Microsoft Excel. Terdapat 4 sheet yang berisi masing masing : data pasien (imunisasi), form PD3I, dan Form surveilans imun pkm-dinas (Form Rekapan). Berikut adalah tampilan tabel data pasien, apabila petugas telah mengisi data pasien melalui tabel data pasien. 


\subsection{Bentuk Output}

\section{Pemakaian NIK untuk kode registrasi pasien}

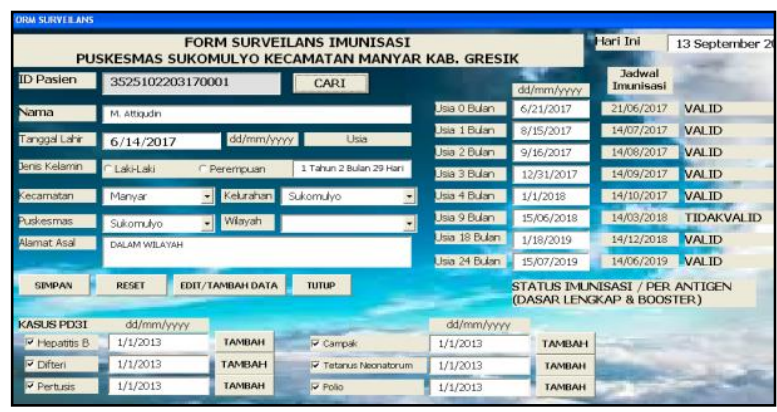

Gambar 5 : Gambar Form Surveilans Imunisasi yang berisi NIK pasien

\section{Persentase Cakupan Imunisasi dasar} Lengkap

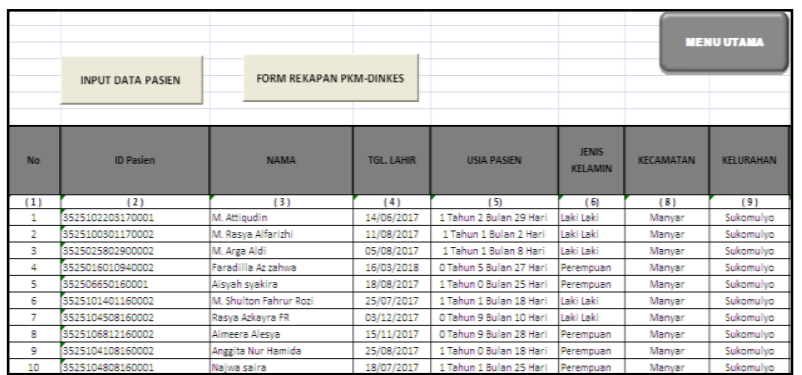

Gambar 6 : Gambar cakupan imunisasi dasar lengkap untuk data individu di Microsoft excel

3. Jumlah Balita yang diimunisasi pada tiap periode

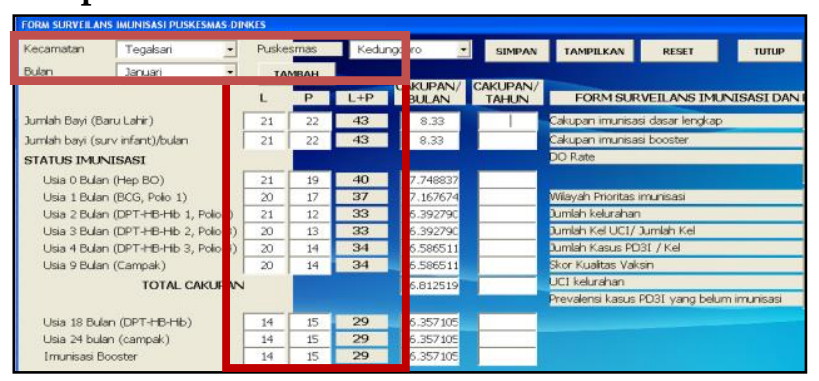

Gambar 7 : Gambar jumlah imunisasi dasar lengkap untuk data individu

\section{Kualitas Pemberian Vaksin}

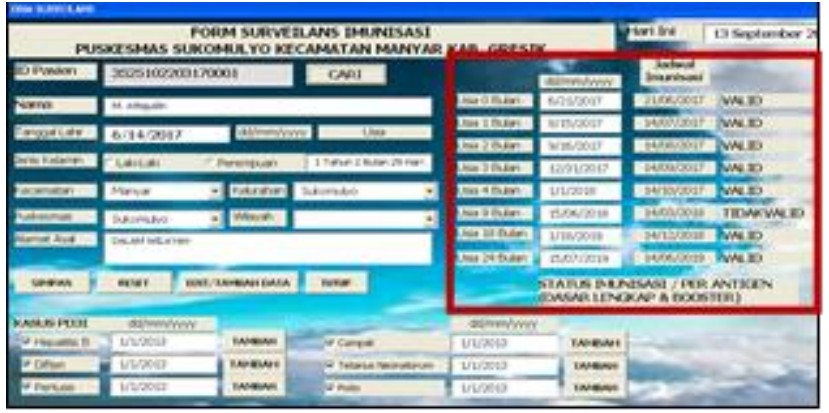

Gambar 8 : Gambar jumlah imunisasi dasar lengkap untuk data
5. Persentase UCI/Per Kelurahan

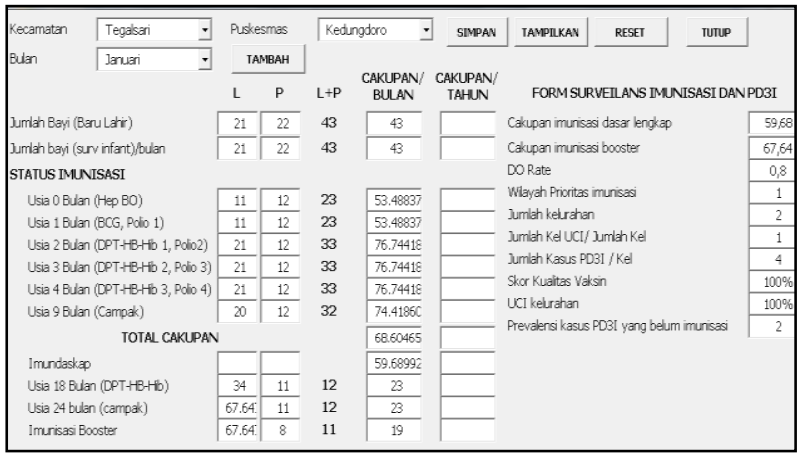

Gambar 9 : Gambar tampilan Persentase UCI/Kelurahan

\section{Jumlah Kasus PD3I per Kelurahan}

\begin{tabular}{|c|c|c|c|c|c|c|c|c|c|c|}
\hline \multirow{3}{*}{\multicolumn{2}{|c|}{ 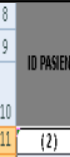 }} & \multirow{3}{*}{ MAHA } & \multirow{3}{*}{$\begin{array}{l}\text { TGL LAHR } \\
\text { (4) } \\
\end{array}$} & \multirow{3}{*}{$\begin{array}{c}\text { KeluphaAl } \\
\text { (9) } \\
\end{array}$} & \multirow{3}{*}{$\begin{array}{l}\text { PISKKEWHAS } \\
\text { (11) } \\
\end{array}$} & \multirow{2}{*}{\multicolumn{2}{|c|}{$\begin{array}{l}\text { RASUS PQ31/PER } \\
\text { AIMGGEI }\end{array}$}} & \multirow{3}{*}{ 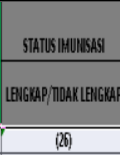 } & \multirow{2}{*}{\multicolumn{2}{|c|}{ 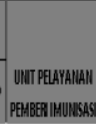 }} \\
\hline & & & & & & & & & & \\
\hline & & & & & & (14) & (15) & & (27) & 128) \\
\hline 12 & 1 & RANII & $1 / 2 / 2013$ & Kestuggoro & Kesdungovoro & OFflen & 1/1/2013 & TIDAK LEVGKAP & PRM & \\
\hline 13 & 2 & OWI & 2/3/2014 & Tegad sari & Ketungedoro & DFFEA & & TDAK LENGKAP & & BPM \\
\hline 14 & 3 & AENIG & 4/1/2015 & Tegalsari & Kedungedoro & & & TIDK LEVGKSP & & BPM \\
\hline 15 & 0 & 0 & 0 & Kestungloro & Kedingloboro & & & TIDK LEVGAPP & & BPM \\
\hline 16 & 0 & 0 & 0 & Kestungoboro & Kesdungoloro & & & TIDAK LEGGASP & & BPM \\
\hline 17 & 0 & 0 & 0 & Kedungoboro & Kesdungotoro & & & & & \\
\hline 18 & 0 & 0 & 0 & Tegabsari & Kesdingeoro & & & & & \\
\hline 19 & 0 & 0 & 0 & & 0 & & & & & \\
\hline
\end{tabular}

Gambar 10 : Tampilan tabel kasus PD3I

\section{Kelurahan dengan Kasus PD3I}

\begin{tabular}{|c|c|c|c|c|c|c|c|c|c|}
\hline KEUUPAHAN & PUSKBMAS & ASAL HaAYAH & & & & & & & KaSUS P PO3/ / PERANIIGEI \\
\hline (9) & (11) & (11) & (1) & (13) & (14) & (15) & (16) & (II) & (18) \\
\hline Kedungdoro & Kedungtoro & Dalamiail & HEPATITIS & 1/1/2013 & DIFERI & 1/1/2013 & PerTuIs & 1/1/2013 & CAMPAK \\
\hline Tegalsari & Keddungtoro & DalanWil & & & DIFERA & & & & \\
\hline Tegalsari & Kedingadoro & Dalanwil & & & & & & & CAMPAK \\
\hline Kedungotoro & Kedungtoro & Dalamivil & & & & & & & CAMPAK \\
\hline Kedungotoro & Keddungtoro & Dalanwil & & & & & & & CAMPAK \\
\hline Ketungotoro & Keddungdoro & Dalamivil & HEPAITITIS & & & & & & \\
\hline \multirow[t]{3}{*}{ Tegalsari } & Keddungtoro & Dalankial & & & & & & & CAMPAK \\
\hline & 0 & 0 & & & & & & & \\
\hline & 0 & 0 & & & & & & & \\
\hline
\end{tabular}

Gambar 11 : Tampilan data kasus PD3I per kelurahan

8. Wilayah Prioritas Program Imunisasi

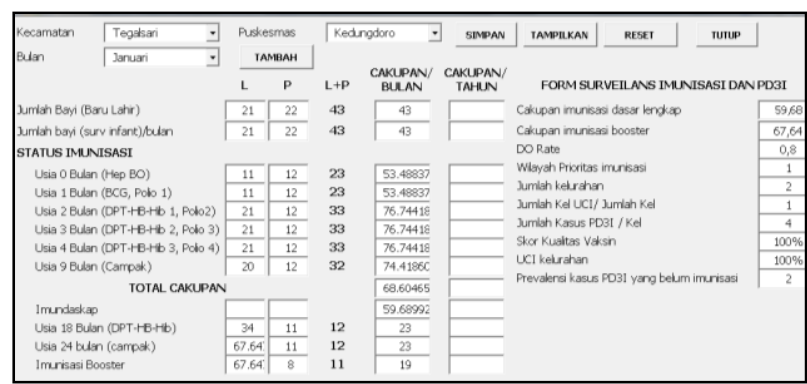

Gambar 12 : Tampilan data Wilayah Prioritas program Imunisasi

Pengembangan sistem informasi surveilans imunisasi dan PD3I selanjutnya akan di uji coba untuk mengetahui kemudahan dan kemanfaatan sistem yang telah dikembangkan. Subjek dari uji coba ini adalah petugas imunisasi 4 orang di 
puskesmas Sukomulyo (Kepala Puskesmas, Pemegang Program Imunisasi, IT/KA TU dan Bidan Koordinator), 5 Orang Bidan Desa, petugas KIA 3 dan Petugas Loket 1.

Evaluasi Sistem Informasi Surveilans Imunisasi dan PD3I dengan menggunakan dua variable, yaitu: Kemudahan penggunaan (ease of use) dan Kemanfaatan (usefulness).

Setelah dilakukan tahapan uji coba dan evaluasi Sistem Informasi Surveilans Imunisai, maka perlu disampaikan rekomendasi kepada Kepala Puskesmas supaya Sistem Informasi Surveilans Imunisai yang sudah dikembangkan ini dapat berjalan.

Hasil rekomendari adalah sebagai berikut :

1. Pembuatan buku panduan dan penyusunan Standar Operasional Prosedur (SOP)

2. Menyediakan tenaga dan fasilitas yang berhubungan dengan back up data mengingat sistem komputerisasi yang dijalankan rawan dengan terjadinya error system

3. Mengadakan pelatihan dan pendampingan rutin terutama pada petugas puskesmas untuk menjalankan Sistem Informasi Surveilans Imunisai.

Menurut Sutabri, T, 2010 menyatakan bahwa pada komponen proses uji coba yakni melakukan kegiatan pengisian atau entry data imunisasi dan kasus, analisis data, menyimpan, dan memanggil kembali atau menampilkan data atau informasi yang telah disimpan. Pada komponen output yaitu sistem informasi surveilans imunisasi menghasilkan suatu informasi yang dibutuhkan untuk monitoring, evaluasi dan alat bantu dalam pengambilan keputusan oleh pemegang program.

\subsection{Pembahasan}

Pengembangan model basis data pada sistem informasi surveians imunisasi dan PD3I berperan penting dalam sistem informasi, antara lain sebagai sumber penyedia data untuk memenuhi kebutuhan informasi bagi pengguna atau pengambil keputusan. Pengembangan basis data ini merupakan perancangan pengelolaan berbagai data yang disimpan dalam file, sehingga satu dengan yang lainnya dapat dihubungkan membentuk suatu informasi. Pengembangan basis data pada sistem informasi surveilans imunisasi dan PD3I ini menggunakan tahapan pembuatan diagram konteks, Normalisasi data, dan Entity Relationship Diagram (ERD).

Tahapan yang dilakukan dalam merancang aplikasi adalah dengan membuat view pada program Microsoft Visual Basic untuk mendesain instrumen untuk entry data atau pengumpul data individu di puskesmas. Data yang telah di entry pada Microsoft Visual Basic akan otomatis masuk pada basis data pada program Microsoft excel. Pada view Microsoft Visual Basic berisi kolom kosong yang nantinya akan diisi identitas pasien, status imunisasi dasar lengkap, serta kualitas pemberian vaksin, dan data kasus PD3I.

Tahapan uji coba meliputi persiapan uji coba dan pelaksanaan uji coba. Pada tahap persiapan uji coba di bagi dalam komponen input, proses dan output. Dalam komponen input yang dipersiapkan adalah data simulasi imunisasi dan kasus PD3I, informan dalam hal ini 15 orang untuk puskesmas. Tempat pelaksanaan adalah di puskesmas Sukomulyo. Informan dibekali dengan buku panduan (Manual Book) Sistem informasi surveilans imunisasi. Buku petunjuk yang digunakan dalam kegiatan Uji Coba Sistem informasi ini adalah buku manual penggunaan sistem informasi surveilans imunisasi yang sudah disusun oleh peneliti.

Evaluasi Sistem Informasi Surveilans Imunisasi dan PD3I dengan menggunakan variable, yaitu: Kemudahan penggunaan (ease of use) dan Kemanfaatan (usefulness). Berdasarkan hasil kuesioner uji coba, semua informan peserta uji coba Sistem Informasi Surveilans Imunisasi dan PD3I menyatakan bahwa untuk melakukan entry data pada program visual basic sudah cukup mudah, demikian pula untuk memanggil kembali data yang diinginkan serta melakukan analisi data, hanya saja membutuhkan waktu untuk memahami perintah-perintah dalam analisis data serta pemahaman terhadap variabel-variabel yang akan dianalisis. Semua informan menyatakan bahwa sistem informasi surveilans imunisai dan PD3I ini sangat bermanfaat, terutama untuk integrasi data surveilans PD3I dan Imunisasi. Informan juga dapat melihat valid atau tidaknya pemberian imunisasi dengan cara membandingkan tanggal pemberian imunisasi dengan tanggal jadwal imunisasi.

\section{Simpulan dan Saran}

\subsection{Simpulan}

1. Sistem informasi program surveilans imunisasi yang sudah berjalan selama ini di Puskesmas Sukomulyo Kecamatan Manyar Kabupaten Gresik meliputi keseluruhan komponen input, proses dan output. Komponen input terdiri dari data, sumber daya manusia dan sarana prasarana yang 
digunakan dalam program imunisasi. Komponen proses terdiri dari pengumpulan data, kelengkapan dan ketepatan dalam pengumpulan data, pengolahan, analisis dan penyajian data dalam bentuk laporan imunisasi dan kasus PD3I. Output yang dihasilkan dari masing masing sistem belum terintegrasi dengan baik, sehingga perlu ada sistem yang mengintegrasikan data dari imunisasi dan PD3I, data tersebut adalah kualitas pemberian vaksin data imunusasi dan data kasus yang dihubungkan dengan ID pasien/NIK.

2. Pada hasil identifikasi kebutuhan data dan informasi masih terdapat beberapa masalah diantaranya ID pasien yang tidak seragam antara pelayanan kesehatan (imunisasi), adanya duplikasi dalam pencatatan data, penyimpanan data yang masih manual dan kelengkapan dan ketepatan laporan masih $70 \%$ untuk imunisasi dari Rumah Sakit Swasta.

3. Pengembangan Sistem informasi surveilans imunisasi dimulai dengan membuat diagram konteks. Sumber data dikumpulkan berdasarkan variabel yang telah disepakati dari hasil wawancara. Tahap pengembangan Sistem informasi surveilans imunisasi dan PD3I yaitu merumuskan Data Flow Diagram (DFD). Model basis data yang digunakan pada Sistem informasi surveilans imunisasi dan PD3I yaitu Entity Relationship Diagram (ERD) yang merupakan suatu model data yang dikembangkan berdasarkan obyek.

4. Tahapan yang dilakukan dalam menyusun aplikasi adalah dengan membuat view pada program Microsoft Visual Basic untuk mendesain instrumen untuk entry data atau pengumpul data individu di puskesmas. Data yang telah di entry pada Microsoft Visual Basic akan otomatis masuk pada basis data pada program Microsoft excel. Pada view Microsoft Visual Basic berisi kolom kosong yang nantinya akan diisi identitas pasien, status imunisasi dasar lengkap dan booster, serta kualitas pemberian vaksin, dan data kasus PD3I.

5. Uji Coba Sistem Informasi Surveilans Imunisasi dan PD3I dengan menggunakan variable, yaitu: Kemudahan penggunaan (ease of use) dan Kemanfaatan (usefulness). Berdasarkan hasil kuesioner uji coba, semua informan peserta uji coba Sistem Informasi Surveilans Imunisasi menyatakan bahwa untuk melakukan entry data pada program visual basic sudah cukup mudah dan bermanfaat

\subsection{Saran}

1. Berdasarkan kemudahan dan kemanfaatan yang dapat dihasilkan oleh Sistem informasi surveilans imunisasi yang telah dikembangkan, sebaiknya sistem pencatatan dan pelaporan kegiatan imunisasi dan surveilans PD3I ke depannya Puskesmas Sukomulyo Kecamatan Manyar Kabupaten Gresik bisa menggunakan Sistem informasi surveilans imunisasi yang telah disusun ini.

2. Kegiatan Pencatatan dan pelaporan dalam Sistem informasi surveilans imunisasi diharapkan dapat dilakukan pada periode bulanan, maka dibutuhkan sarana dan prasarana seperti komputer yang khusus untuk melakukan kegiatan pencatatan dan pelaporan imunisasi dan PD3I.

3. Diperlukan sosialisasi, pelatihan sederhana dan adanya buku panduan untuk meningkatkan kemampuan petugas dalam mengentry data, membuat rekap data, memanggil kembali data yang dibutuhkan serta menganalisis data sehingga mampu menghasilkan laporan yang lengkap dan akurat.

\section{Ucapan Terimakasih}

1) Direktorat Riset dan Pengabdian Masyarakat Direktorat jenderal Penguatan Riset dan Pengembangan Kementerian Riset, Teknologi, dan Pendidikan Tinggi

2) Koordinator Kopertis VII wilayah Jawa Timur

3) Ir. Tugas Husni Syarwanto, M. MT selaku Kepala Badan Perencanaan Pembangunan, Penelitian dan pengambangan Daerah (BAPEDDA) Kabupaten Gresik

4) UPPM Poltekkes Kemenkes Semarang

5) dr. Abdur Rivai, M.Kes selaku Ketua STIKes Delima Persada Gresik

6) dr. Anik Lutfiyah, M.Ked.Trop selaku Kepala UPT Puskesmas Sukomulyo Kecamatan Manyar

7) Bidan Koordinator Puskesmas Sukomulyo Kecamatan Manyar

8) Koordinator Program Imunisasi Puskesmas Sukomulyo Kecamatan Manyar

9) Karyawan/Karyawati Puskesmas Sukomulyo Kecamatan Manyar

10)Semua teman- teman sejawat STIKes Delima Persada Gresik 


\section{Daftar Pustaka}

Atikah, P, Siti, M. 2010. Imunisasi dan Vaksinasi. Jakarta : Nuha Medika.

Depkes RI., (2011) Angka cakupan imunisasi di tahun 2010, Direktorat Surveilans Epidemiologi, Imunisasi, dan Kesehatan Matra, Direktorat Jenderal Pengendalian Penyakit dan Penyehatan Lingkungan Departemen Kesehatan Indonesia, Jakarta, hlmn 43

Dinas Kesehatan Kabupaten Gresik., (2012) Profil Kesehatan Tahun 2012, Gresik, hlmn 135

Dinas Kesehatan Kabupaten Gresik., (2013) Profil Kesehatan Tahun 2013, Gresik, hlmn 132

Dinas Kesehatan Kabupaten Gresik., (2014) Profil Kesehatan Tahun 2013, Surabaya, hlmn 135

Dinas Kesehatan Kabupaten Gresik., (2015) Profil Kesehatan Tahun 2013, Surabaya, hlmn 135

Direktorat Jenderal PPM dan PL., (2015) Pedoman tehnis Pengelolaan vaksin dan Rantai vaksin, Jakarta, Departemen Kesehatan RI, hlmn 187-201

Hidayat., (2008) Imunisasi dan penyakit imun, Jakarta : Salemba Medika, hlmn 76-77

Jerry Fitz Grerald., Wareend D Jr., (2010) Fundamental of system analysis, New York, p 5

Kemenkes RI., (2015) Program Imunisasi Bayi, Ibu Hamil Dan Batita, Jakarta : Kemenkes RI, hlmn 27
Maryunani., (2010) Buku ajar Imunisasi untuk anak, Jakarta : EGC, hlmn 76-78

Mulyani., (2013) Imunisasi untuk anak, Jakarta : trans info media, hlmn 22

Nurul, K, dkk., (2016) PENGEMBANGAN BASIS DATA SISTEM SURVEILANS CAMPAK BERBASIS KASUS ATAU CASE BASED MEASLES SURVEILLANCE (CBMS) DI DINAS KESEHATAN KABUPATEN SIDOARJO, Tesis, FK Universitas Airlangga, Surabaya

Permenkes 45., (2013) Penyelenggaraan surveilans Kesehatan, Jakarta: Kemenkes RI, hlmn $4-10$

PP IDAI., (201) Pedoman Imunisasi di Indonesia, Edisi 4, Jakarta : Badan penerbit Ikatan Dokter Anak Indonesia, hlmn 255-326

Riyadi., (2009) Asuhan Keperawatan pada anak: Imunisasi pada anak di Indonesia, Jakarta : Graha ilmu, hlmn 23

Sanusi, R, dkk., (2014) Kebijakan Surveilans Respons dan Sistem Informatika Kesehatan di pusat dan didaerah sentralisasi, Health Policy Brief, Media FK UGM, Yogyakarta, hlmn 1-6

Wahab A.Samik (2012) Sistem imun, imunisasi, dan penyakit imun. Jakarta: Widya Medika. hlmn. 13

WHO., (2015) Global Immunization Data, UNICEF, p 1-4 